\title{
Behaviour of Australian rainforest stream frogs may affect the transmission of chytridiomycosis
}

\author{
Jodi J. L. Rowley*, Ross A. Alford \\ School of Marine and Tropical Biology, James Cook University, Townsville, Queensland 4811, Australia
}

\begin{abstract}
The amphibian disease chytridiomycosis, caused by the pathogen Batrachochytrium dendrobatidis, has been implicated in mass mortalities, population declines and extinctions of amphibians around the world. In almost all cases, amphibian species that have disappeared or declined due to chytridiomycosis coexist with non-declining species. One reason why some species decline from chytridiomycosis and others do not may be interspecific differences in behaviour. Host behaviour could either facilitate or hinder pathogen transmission, and transmission rates in the field are likely to vary among species according the frequency of factors such as physical contact between frogs, contact with infected water and contact with environmental substrates containing $B$. dendrobatidis. We tracked 117 frogs (28 Litoria nannotis, 27 L. genimaculata and 62 L. lesueuri) at 5 sites where $B$. dendrobatidis is endemic in the rainforest of tropical northern Queensland and recorded the frequency of frog-to-frog contact and the frequency of contact with stream water and environmental substrates. Frequency of contact with other frogs and with water were highest in L. nannotis, intermediate in L. genimaculata and lowest in L. lesueueri. Environmental substrate use also differed among species. These species-specific opportunities for disease transmission were correlated with conservation status: $L$. nannotis is the species most susceptible to chytridiomycosis-related declines and $L$. lesueuri is the least susceptible. Interspecific variation in transmission probability may, therefore, play a large role in determining why chytridiomycosis drives some populations to extinction and not others.
\end{abstract}

KEY WORDS: Batrachochytrium dendrobatidis - Amphibian chytrid fungus - Chytridiomycosis · Disease transmission $\cdot$ Behaviour $\cdot$ Frogs

Resale or republication not permitted without written consent of the publisher

\section{INTRODUCTION}

Approximately one-third of all known amphibian species are currently listed as threatened (Stuart et al. 2004). Declines of many amphibian species are attributed to the disease chytridiomycosis (Berger et al. 1998), which has been implicated in mass mortalities, population declines and local extinctions in Australia, New Zealand, Central and North America, Europe and Africa (Berger et al. 1998, Bosch et al. 2001, Bradley et al. 2002, Muths et al. 2003, Bell et al. 2004, Weldon \& Du Preez 2004, Lips et al. 2005, 2006, Rachowicz et al. 2006). Chytridiomycosis is caused by the fungal pathogen Batrachochytrium dendrobatidis, which belongs to the order Chytridiales (Longcore et al. 1999). It is the only chytrid known to cause disease in vertebrate hosts
(Berger et al. 1998), and infects keratinized tissues in the epidermis of metamorphosed amphibians (Longcore et al. 1999) and the mouthparts of larval anurans (Fellers et al. 2001, Rachowicz \& Vredenburg 2004). Chytridiomycosis can cause rapid mortality (Nichols et al. 2001), with frogs of susceptible species dying $<3 \mathrm{wk}$ after experimental infection in the laboratory (Berger et al. 1998, 2004, 2005). The only known mechanism of transmission among hosts, and of intrahost increase in pathogen load, is via infection and re-infection by motile, waterborne zoospores (Longcore et al. 1999).

In almost all cases, amphibian species that have disappeared or declined due to chytridiomycosis coexist with non-declining species (McDonald \& Alford 1999, Lips \& Donnelly 2002, Retallick et al. 2004, Lips et al. 2006). One reason why some species decline from 
chytridiomycosis and others do not may be interspecific differences in behaviour. Transmission can be the driving force in the dynamics of infectious diseases (Begon et al. 2002), and the long-term spread and persistence of many diseases depends largely on the contact rate between susceptible hosts and infectious pathogens (Swinton 1998). This suggests that differences among species in opportunities for the transmission of Batrachochytrium dendrobatidis may affect their susceptibility to chytridiomycosis. Despite the importance of transmission in the epidemiological process, very little is known about transmission of $B$. dendrobatidis, particularly in the field. The only route of transmission that has been established by controlled experimentation is transmission via contact with water that was previously in contact with infected tadpoles or adults (Berger et al. 1998, Retallick 2002, Parris \& Cornelius 2004, Rachowicz \& Vredenburg 2004). However, infective zoospores are present on, and can be recovered from, the skin surfaces of infected animals (Berger et al. 1998, Pessier et al. 1999), and B. dendrobatidis DNA has been detected on wet rocks at a site during an epidemic (Lips et al. 2006). It therefore seems likely that transmission also occurs via contact with infected individuals or contaminated environmental substrates.

Host behaviour could either facilitate or hinder pathogen transmission, and transmission rates in the field are likely to vary among species depending on the frequency of behaviours such as physical contact between frogs, contact with infected water and contact with environmental substrates that may contain Batrachochytrium dendrobatidis. In this study, we tracked 3 species of rainforest stream frogs at 5 sites and recorded their frequency of contact with other frogs, contact with stream water and contact with environmental substrates.

\section{MATERIALS AND METHODS}

The study was conducted at 5 tropical rainforest sites in northern Queensland, Australia: Birthday Creek, Paluma State Forest (18 58' 54" S, 146 $16^{\circ} 10^{\prime} 02^{\prime \prime}$ E, 800 m above sea level [a.s.l.]), Python Creek $\left(17^{\circ} 46^{\prime} \mathrm{S}\right.$, $145^{\circ} 35^{\prime} \mathrm{E}, 200 \mathrm{~m}$ a.s.l.), an unnamed creek $\left(17^{\circ} 48^{\prime} \mathrm{S}\right.$, $145^{\circ} 41^{\prime} \mathrm{E}, 70 \mathrm{~m}$ a.s.l.) in Tully Falls Forest Reserve, an unnamed creek in Kirrama State Forest $\left(18^{\circ} 11^{\prime} \mathrm{S}\right.$, $145^{\circ} 52^{\prime} \mathrm{E}, 200 \mathrm{~m}$ a.s.l.) and Frenchman Creek, in Wooroonooran National Park $\left(17^{\circ} 20^{\prime} \mathrm{S}, 145^{\circ} 55^{\prime} \mathrm{E}, 20\right.$ to $100 \mathrm{~m}$ a.s.1.). All sites were relatively undisturbed rainforest streams with rocky beds. All streams had pools and riffles, and most sites had a number of waterfalls.

Frogs of 3 species were tracked: the stony creek frog Litoria lesueuri, which has not experienced population declines (IUCN 'least concern'; see below), the greeneyed tree frog L. genimaculata, which declined and then recovered (IUCN 'least concern'; however, Australian populations of this species are considered to be 'near threatened') and the waterfall frog L. nannotis, which has experienced large and long-lasting population declines (IUCN 'endangered'; McDonald \& Alford 1999, McDonald 2002, McDonald et al. 2005, IUCN et al. 2006). Recently, the taxonomy of the L. lesueuri group has been revised (Donnellan \& Mahony 2004). Two species, L. jungguy and L. wilcoxii, occur in sympatry at the study sites, hybridise, and are indistinguishable on the basis of morphology (Donnellan \& Mahony 2004). Population declines have not been observed in the region for either species (McDonald \& Alford 1999, McDonald et al. 2005). We therefore continue to refer to the study population as L. lesueuri, while recognising that the population contains 2 morphologically indistinguishable species. All species of frogs tracked were large- to medium-sized hylids (males 5.4 to $12.5 \mathrm{~g}$, females 6.5 to $41.3 \mathrm{~g}$ ), and were tracked using either radio-telemetry or harmonic direction finding.

Only frogs weighing $>11 \mathrm{~g}$ were tracked via radiotelemetry. Radio transmitters (Models BD-2N and BD-2NT; Holohil Systems; weighing approximately $0.67 \mathrm{~g}$, including a harness and with a battery life of approximately $3 \mathrm{wk}$ ) were attached to a harness made of silicone tubing, designed to minimise restrictions on movement and avoid causing discomfort to the frog. This harness/transmitter combination was placed around the waists of frogs. Frogs that were too small to be radio-tracked, and a number of larger individuals, were tracked using harmonic direction finding (Langkilde \& Alford 2002). This required attachment of a small diode with whip antenna to the same specially designed harness (total weight approximately $0.23 \mathrm{~g}$ ), which was then placed around the waist of a frog. Tracking devices were fitted in situ, and frogs were released at the point of capture after $<5$ min of handling. Frogs wearing either tracking device always had harnesses and associated equipment that weighed $<6 \%$ of their total body weight, just over half the recommended maximum relative weight for an attached $\operatorname{tag}(10 \%$ of the body weight; Richards et al. 1994).

Frogs fitted with radio-transmitters were tracked using a Telonics TR-4 Tracking Receiver (Telonics; 2004 wet season only) and a HABIT Research HR2500 Osprey VHF Receiver (HABIT Research); we used a 3-element folding Yagi antennae with both receivers (A.F. Antronics). Frogs fitted with diodes were tracked using a portable RECCO R5 transmitter-receiver (Recco Rescue Systems). The system consists of a hand-held device that acts as both the transmitter and receiver, and a battery and earphones. Tags were self- 
built using commercial germanium diodes (see Langkilde \& Alford 2002 for a description of methodology).

Surveys lasted $16 \mathrm{~d}$ and were conducted in July to September (the cool/dry season) and February to March (the warm/wet season) for each species at 2 sites, except for Paluma, which was only surveyed in the warm/wet season. Litoria genimaculata was tracked at Paluma in late 2003, L. genimaculata and L. nannotis were tracked simultaneously at Kirrama and Tully Gorge during 2004, and L. lesueuri was tracked at Lower Tully and Babinda during 2005. During surveys, the location of each frog was determined once during the day (09:00 to 18:00 h) and once at night (19:00 to 04:00 h).

We recorded instances of frog-to-frog contact when we observed direct skin-to-skin contact between frogs and when aggregations of $>3$ individuals occupied an area of less than $0.3 \times 0.3 \mathrm{~m}$. At each observation of contact between frogs, we recorded the species involved and the nature of the contact (i.e. amplexus, sharing a retreat site or a nocturnal perch site). We recorded instances of contact with water when we observed at least part of the frog in contact with stream water, or when the frog had crossed the stream since the last observation, and there was no way for the frog to cross the stream without entering the stream water (i.e. the frog could not have crossed the stream using dry rocks or overhead vegetation). This provides an estimate of the minimum rate of contact with water, since frogs may come into contact with water without crossing streams. During all observations, we recorded the substrate type with which the ventral surface of the frog was in contact. Substrate type was classified into 6 categories: bare ground, dry rock, leaf litter, vegetation, wood (dead wood such as logs or sticks) and wet rock. All these records represent possible contact between host and pathogen, or opportunities for transmission.

We excluded data from the night following tag attachment due to the potential short-term behavioural effects of handling (Langkilde \& Alford 2002). Any effects are unlikely to persist after the first night of tag attachment (Rowley \& Alford 2007). To avoid pseudoreplication or biasing our results towards frogs that were located more frequently, we used individuals as replicates and compared summary statistics calculated for each animal. To analyse frog-to-frog contact and contact with water, we performed KruskalWallis tests to detect differences among species and separate Mann-Whitney $U$ tests for each species to detect differences with respect to season and sex. We used Bonferroni adjustments to control Type I error rates. To analyse substrate use, we examined diurnal and nocturnal data separately, due to obvious differences between the diurnal and nocturnal behaviour of all species. We then performed multiresponse permutation procedures (MRPP) using Blossom statistical software (Cade \& Richards 2005). We performed the analysis in a stepwise fashion, testing for differences between species, sexes, seasons and sites, in that order. If a difference was detected between groups, the next analysis was performed on each of those groups separately. We used Monte Carlo hypothesis testing, with 20000 iterations.

\section{RESULTS}

A total of 117 frogs (28 Litoria nannotis: $6 \mathrm{M}, 22 \mathrm{~F}$; 27 L. genimaculata: $15 \mathrm{M}, 12 \mathrm{~F}$; and $62 \mathrm{~L}$. lesueuri: $32 \mathrm{M}, 30 \mathrm{~F}$ ) were tracked during the study period. Approximately equal numbers of frogs were tracked using both tracking techniques; 61 (52\%) were tracked via radio-telemetry. Throughout the survey periods, a total of 2111 fixes or locations of individual frogs were obtained. On average, each frog was located 17 times (minimum 5, maximum 29).

The frequency of contact between frogs differed significantly among species (Table 1, Fig.1). Individual Litoria nannotis were in contact with other frogs during an average $28 \%$ of observations, while L. genimaculata and $L$. lesueuri were only in contact with other frogs during an average of 3 and $2 \%$ of observations, respectively. Type of contact differed among species (Table 2); however, in all species, direct contact was always between conspecifics. The frequency of physical contact differed between seasons only in L. nannotis, which was more often in contact with conspecifics in the warm/wet season (Table 1, Fig. 1). There was no difference in the frequency of physical contact between sexes in L. nannotis and L. genimaculata, but

Table 1. Litoria spp. Differences in direct and indirect contact among species (Kruskal-Wallis tests), between seasons and between sexes (Mann-Whitney $U$-tests). ${ }^{*}$ Significance at the Bonferroni-adjusted 0.05 level

\begin{tabular}{|llcccc|}
\hline Test & Species & \multicolumn{3}{c}{$\begin{array}{c}\text { Frog-to-frog contact } \\
\text { Test statistic }\end{array}$} & \multicolumn{2}{c|}{$\begin{array}{c}\text { Contact with stream water } \\
\left(\chi^{2} \text { or } Z\right)\end{array}$} & & Test statistic & p \\
& & $\chi^{2}$ or $\left.Z\right)$ & \\
\hline Species & - & 18.573 & $<0.001^{*}$ & 60.492 & $<0.001^{*}$ \\
Season & L. lesueuri & -1.008 & 0.313 & -3.607 & $<0.001^{*}$ \\
& L. genimaculata & -0.789 & 0.648 & -0.960 & 0.347 \\
& L. nannotis & -2.775 & $0.010^{*}$ & -1.004 & 0.324 \\
Sex & L. lesueuri & -2.636 & $0.008^{*}$ & -0.993 & 0.321 \\
& L. genimaculata & -0.395 & 0.829 & -0.541 & 0.614 \\
& L. nannotis & -0.852 & 0.460 & -1.887 & 0.059 \\
\hline
\end{tabular}



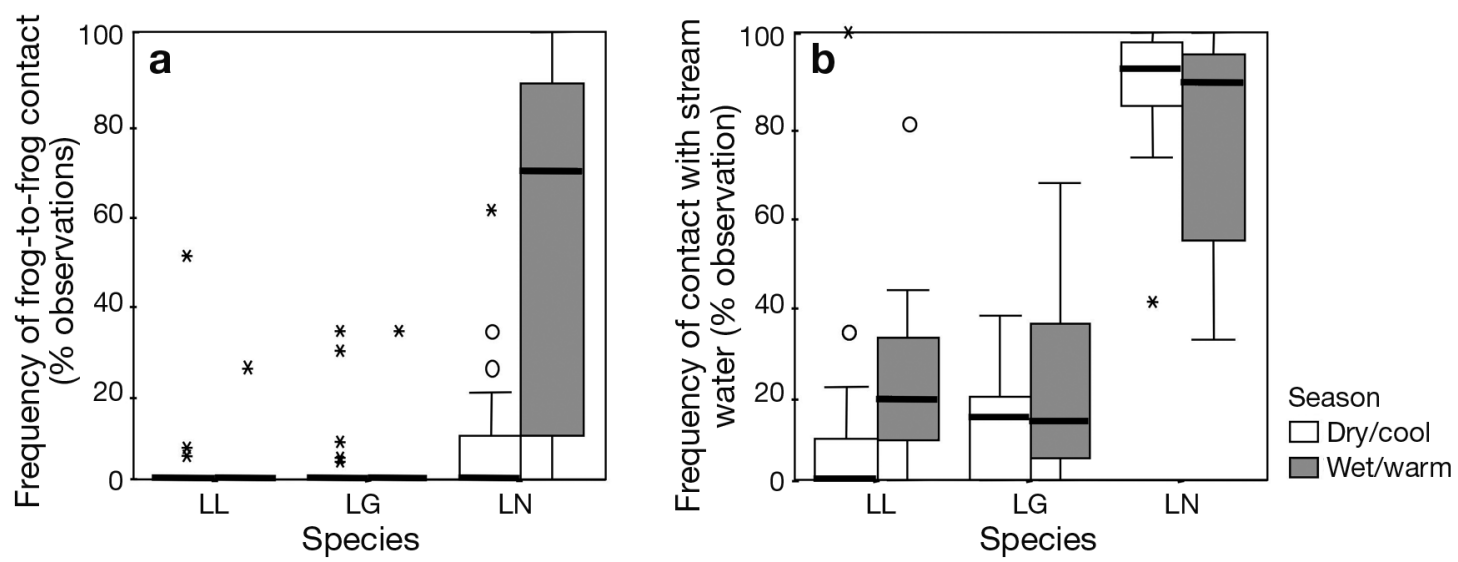

Fig. 1. Litoria spp. Frequency of (a) frog-to-frog contact and (b) contact with stream water (\% of observations) in L. lesueuri (LL), L. genimaculata (LG) and L. nannotis (LN) in the wet and dry seasons. Bold horizontal lines represent the median, boxes indicate the locations of upper and lower quartiles, bars encompass values up to 1.5 interquartile range, open circles represent values $>1.5$ interquartile ranges from the nearest quartile and stars indicate data $>3$ interquartile ranges from the nearest quartile

Table 2. Litoria spp. Frequency (and percent) of each type of frog-to-frog contact observed in this study

\begin{tabular}{|lcll|}
\hline & Retreat site & Amplexus & Perch site \\
\hline L. lesueuri & $2(29 \%)$ & $5(71 \%)$ & 0 \\
L. genimaculata & 0 & $2(50 \%)$ & $2(50 \%)$ \\
L. nannotis & $45(100 \%)$ & 0 & 0 \\
\hline
\end{tabular}

female $L$. lesueuri were more often in contact than male L. lesueuri (Table 1).

The frequency of contact with stream water also differed significantly among species, and was highest in Litoria nannotis (Table 2, Fig. 1). Overall, L. nannotis was observed in stream water or had crossed the stream since the last observation during $84 \%$ of observations. In contrast, L. genimaculata and L. lesueuri were observed in contact with water during an average of only 16 and $13 \%$ of observations, respectively. Most contact with water in L. genimaculata and $L$. lesueuri occurred at night, when the species were active and crossing the stream, in contrast to L. nannotis, which was often inactive and in contact with water for long periods of time $(>12 \mathrm{~h})$. We observed a number of these individuals crossing the stream, and in all cases these crossings were relatively brief $(<2 \mathrm{~h})$. Rates of contact with stream water differed between seasons only in L. lesueuri; they were higher in the wet season (Table 2, Fig. 1) and did not differ with sex for any species (Table 2).

Substrate use differed among species and between diurnal and nocturnal surveys (Tables $3 \& 4$ ). Litoria lesueuri were most often on bare ground or leaf litter during diurnal surveys, moving onto a wider range of substrate types at night. L. genimaculata were most often on vegetation, generally in the forest canopy, during both diurnal and nocturnal surveys. In instances when we could visually locate individual $L$. genimaculata in the canopy, frogs were sitting on leaves at the ends of branches. L. nannotis was most commonly on wet rock, with frogs typically sheltering under large boulders in the stream during the day and often moving on to terrestrial vegetation and dry rock at night.

Substrate use differed between sexes in Litoria lesueuri and L. nannotis (Tables $3 \& 4$ ). In L. lesueuri, substrate use differed subtly between sexes, but, in $L$. nannotis, males were almost always on wet rock, while females were found more often on other substrates, including vegetation and dry rock (Table 4). Substrate use differed with season for $L$. lesueuri males and for $L$. genimaculata (Tables $3 \& 4$ ). In the cool/dry season, $L$. lesueuri males spent more time on bare ground and less time on dry rocks and L. genimaculata spent more

Table 3. Litoria spp. Multi-response permutation procedures for differences between species, sex and season using Monte Carlo hypothesis testing. We performed the analysis in a stepwise fashion. If a difference was detected between groups, the next analysis was performed on each of those groups separately. ${ }^{*} \mathrm{p}=0.05$

\begin{tabular}{|lllcc|}
\hline Test & & & $\delta$ & $\mathrm{p}$ \\
\hline Species & & & 4.185 & $<0.001^{*}$ \\
Sex & L. leseuri & & 5.919 & $0.024^{*}$ \\
& L. genimaculata & & 4.870 & 0.548 \\
& L. nannotis & & 4.123 & $0.003^{*}$ \\
Season & L. leseuri & Female & 5.66 & $0.792^{*}$ \\
& L. genimaculata & Male & 4.961 & $<0.001^{*}$ \\
& L. nannotis & Female & 4.251 & $0.011^{*}$ \\
& & & & 0.113 \\
\hline
\end{tabular}


Table 4. Litoria spp. Substrate use. Mean percent (and range) of observations on each substrate type, using individual frogs as replicates. Only categories that are significantly different from each other are shown

\begin{tabular}{|c|c|c|c|c|c|c|c|}
\hline & \multicolumn{3}{|c|}{$\longrightarrow$ L. lesueuri } & \multicolumn{2}{|c|}{ L. genimaculata } & \multicolumn{2}{|c|}{ L. nannotis } \\
\hline & \multirow[t]{2}{*}{ Female } & \multirow{2}{*}{\multicolumn{2}{|c|}{ 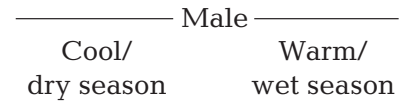 }} & \multirow{2}{*}{$\begin{array}{c}\text { Cool/ } \\
\text { dry season }\end{array}$} & \multirow{2}{*}{$\begin{array}{c}\text { Warm/ } \\
\text { wet season }\end{array}$} & \multirow[t]{2}{*}{ Female } & \multirow[t]{2}{*}{ Male } \\
\hline & & & & & & & \\
\hline \multicolumn{8}{|l|}{ Bare ground } \\
\hline Diurnal & $19.34(0-66.7)$ & $39.01(0-100)$ & $9.1(0-30.8)$ & 0 & $30.4(0-100)$ & 0 & 0 \\
\hline Nocturnal & $8.1(0-33.3)$ & $26.67(0-66.7)$ & $10.4(0-28.6)$ & 0 & $19.7(0-66.7)$ & 0 & 0 \\
\hline \multicolumn{8}{|l|}{ Dry rock } \\
\hline Diurnal & $3.8(0-60)$ & $1.8(0-25)$ & $8.3(0-33.3)$ & $25.6(0-100)$ & $3.3(0-60)$ & $10.5(0-66.7)$ & $2.8(0-12)$ \\
\hline Nocturnal & $8.2(0-50)$ & $2.3(0-33)$ & $20.2(0-60)$ & $21.4(0-69.2)$ & $5.6(0-50)$ & $14.4(0-62.5)$ & $4.1(0-15.4)$ \\
\hline \multicolumn{8}{|l|}{ Leaf litter } \\
\hline Diurnal & $63.6(0-100)$ & $55.3(0-100)$ & $52.9(0-100)$ & $5.9(0-33.3)$ & $57.8(0-100)$ & $0.2(0-5)$ & 0 \\
\hline Nocturnal & $39.9(13.3-85.7)$ & $16.4(0-80)$ & $30.8(0-61.5)$ & $2.8(0-25)$ & $24.8(0-85.7)$ & 0 & 0 \\
\hline \multicolumn{8}{|l|}{ Vegetation } \\
\hline Diurnal & $5.6(0-41.7)$ & $3.4(0-22)$ & $5.9(0-40)$ & $63.7(0-100)$ & $3.5(0-27.3)$ & $20.2(0-55.6)$ & $7.1(0-16)$ \\
\hline Nocturnal & $30.5(0-80)$ & $48.8(0-100)$ & $25.2(0-50)$ & $72.7(23.1-100)$ & $41.6(0-100)$ & $36.4(0-88.9)$ & $9.0(0-30.8)$ \\
\hline \multicolumn{8}{|l|}{ Wood } \\
\hline Diurnal & $2.7(0-33.3)$ & $0.5(0-11.1)$ & $14.7(0-100)$ & 0 & $1.6(0-33)$ & $2.9(0-33.3)$ & 0 \\
\hline Nocturnal & $11.4(0-16.7)$ & $5.8(0-44.4)$ & $5.2(0-20)$ & 0 & $7.9(0-50)$ & $4.3(0-40)$ & 0 \\
\hline \multicolumn{8}{|l|}{ Wet rock } \\
\hline Diurnal & $1.5(0-33.3)$ & 0 & 0 & $4.8(0-22.2)$ & $0.9(0-33.3)$ & $66.2(16.7-96)$ & $90.2(72-100)$ \\
\hline Nocturnal & $1.2(0-16.7)$ & 0 & $8.3(0-60)$ & $3.1(0-22.2)$ & $0.4(0-16.7)$ & $45.0(0-92.3)$ & $88.9(53.9-100)$ \\
\hline
\end{tabular}

time on dry rock and less time on leaf litter, vegetation and bare ground (Table 4).

\section{DISCUSSION}

The frequencies of frog-to-frog contact and contact with stream water and different environmental substrates differed significantly among species. As these factors should affect rates of transmission of Batrachochytrium dendrobatidis via known or highly likely routes, transmission rates should also vary among species.

The frequency of contact between frogs was highest in Litoria nannotis, primarily because the species aggregates at retreat sites. The formation of aggregations by host populations promotes contact between individuals, and in many other host-pathogen systems it is positively correlated with both the prevalence and intensity of contact-transmitted parasites (Anderson \& May 1979, Hoogland 1979, Brown \& Brown 1986, Coté \& Poulin 1995, Ezenwa 2004). Outbreaks of disease are also most commonly observed in aggregations of individuals (Vermeer 1969, Wobeser et al. 1979). In contrast, predominantly solitary or non-social species such as L. lesueuri and L. genimaculata will come into direct contact almost exclusively for reproduction, and it is likely that, for these species, most instances of direct transmission occur at this time (Loehle 1995). This may be especially true for the transmission of Batrachochytrium dendrobatidis in L. lesueuri, as L. lesueuri comes into contact with stream water infrequently. Therefore, while traditional models of direct transmission have assumed that contact rate is directly proportional to host population size or density (Anderson \& May 1979, 1981, Watanabe 1987), the present study confirms that rates of contact between individuals may be almost entirely independent of population size due to host behaviour (Loehle 1995, McCallum et al. 2001, Ezenwa 2004).

In all 3 species, contact between frogs was always between conspecifics, providing almost no opportunities for cross-species pathogen transmission. Therefore, contact with stream water and possibly other environmental substrates that serve as reservoirs are likely to be the main source of transmission between species in this system. Contact with stream water was more frequent in Litoria nannotis, which was in contact with the stream during the majority of observations. Increased frequency of contact with stream water is likely to increase the rate of transmission of Batrachochytrium dendrobatidis in a species for a number of reasons. First, B. dendrobatidis is known to be transmitted via water in the laboratory (Berger et al. 1998, Parris \& Cornelius 2004, Rachowicz \& Vredenburg 2004) and in field enclosures (Retallick 2002). Second, $B$. dendrobatidis zoospores are aquatic, highly sensitive to desiccation (Johnson et al. 2003), and can sur- 
vive and remain infective in the laboratory for at least 7 wk in sterile lake water (Johnson \& Speare 2003). Additionally, tadpoles often have high infection prevalence, may not be susceptible to the pathogen, and can persist in the stream environment for several years (Woodhams \& Alford 2005, Rachowicz et al. 2006), thereby providing a likely continual source of zoospores to the stream. Lastly, amphibian population declines have been greatest in species with strong associations with streams (Williams \& Hero 1998, McDonald \& Alford 1999, Lips et al. 2003, Hero et al. 2005), and, while purely terrestrial species may be infected with $B$. denodrobatidis (Lips et al. 2006), they do not typically experience population declines or experience reduced rates of decline, even when in sympatry with rapidly declining species (Williams \& Hero 1998, McDonald \& Alford 1999, Hero et al. 2005, Lips et al. 2006).

Different species used different environmental substrates, and, in some cases, substrate use varied between sexes and seasons as well. Because the abundance and composition of other chytrids differ among macrohabitats (i.e. vegetation type; Letcher et al. 2004) and microhabitats (i.e. with distance from moss; Letcher \& Powell 2002), it is highly probable that the abundance of Batrachochytrium dendrobatidis zoospores also differs among environmental substrates, and, hence, exposure to $B$. dendrobatidis probably differs among species and even between sexes and seasons for some species. However, there are a large number of uncertainties in quantifying the risks associated with contact with stream water or environmental substrates. There is currently no information on the relative abundance of zoospores in the environment, and we do not yet know the relative importance of different areas of the stream or different environmental substrates for the persistence and transmission of $B$. dendrobatidis in the field. While $B$. dendrobatidis DNA has been detected on environmental substrate samples during epidemics (Lips et al. 2006), it is not known whether these substrates contain viable zoospores. In addition, $B$. dendrobatidis DNA was not detected in environmental substrate samples taken at Litoria lesueuri retreat sites, where $B$. dendrobatidis is endemic (Rowley et al. 2007). More work to determine how important environmental substrates may be as reservoirs for infective zoospores is urgently required.

Frequency of contact with other frogs or with water differed between seasons only in Litoria lesueuri, which was more often in contact with water during the wet season. There was little evidence that the frequency of contact with other frogs or with water differed between sexes for any of the species. In other study species, sex may greatly influence opportunities for disease transmission. For example, host behaviour has been implicated in the differential survival of Bufo boreas during Batrachochytrium dendrobatidis outbreaks (Carey et al. 2006). In this species, adult males spend several weeks in frequent direct contact with other males and in continuous contact with water during the breeding season, while females are thought to spend $<1 \mathrm{~d}$ at breeding sites (Carey et al. 2006). Perhaps because of this, adult females appear to live longer than adult males during outbreaks of $B$. dendrobatidis (Carey et al. 2006).

In addition to frequency of contact between frogs, with stream water or with environmental reservoirs, the duration of contact is likely to be important. In the laboratory, the duration of exposure to Batrachochytrium dendrobatidis can influence the probability of successful transmission and the speed of disease progression, with longer exposures to $B$. dendrobatidis resulting in shorter average survival times in Bufo boreas (Carey et al. 2006). In our study species, the majority of contact situations with water for Litoria lesueuri and L. genimaculata occurred briefly when crossing a stream, while L. nannotis spent all day and often all night in contact with stream water. In addition, L. nannotis often returned to the same retreat sites, which were often shared with a large number of conspecifics, after nocturnal excursions (authors' unpubl. data). Such behaviour is likely to increase the opportunities for transmission in L. nannotis, as parasites may accumulate in the hosts' environment over time (Altizer et al. 2000). Species that rarely return to the same diurnal retreat sites, such as L. lesueuri (author's unpubl. data), may reduce their chances of infection. Although $B$. dendrobatidis was not detected at retreat sites of L. nannotis and L. lesueuri at several of our sites (Rowley et al. 2007), when infection prevalence and intensity is high, the duration of time spent at retreat sites with a certain substrate type (i.e. wet rock) may be important.

The dose of Batrachochytrium dendrobatidis zoospores that a frog encounters may also influence the probability and outcome of infection in frogs. In Bufo boreas, high doses of $B$. dendrobatidis result in shorter average survival times (Carey et al. 2006). This pattern appears typical of other host-pathogen systems, with higher infective doses leading to higher mortality rates and decreased host survival times (van Beek et al. 2000, Arthurs \& Thomas 2001, Brunner et al. 2005). Because the intensity of infection by $B$. dendrobatidis must reach a particular threshold of zoosporangia before individuals succumb to chytridiomycosis, larger inocula are likely to reach lethal levels sooner (Carey et al. 2006). It is currently not known which behaviours would expose frogs to the highest concentration of zoospores, although direct contact with highly infected frogs seems likely to expose individuals to the highest 
zoospore concentrations. Contact with environmental substrates may also expose frogs to high zoospore concentrations if $B$. dendrobatidis is able to grow on these substrates or if long residence times of infected frogs at retreat sites lead to high concentrations of zoospores in the environment.

In this study, it is likely that we underestimated the frequency of contact in all frog species. As frogs were not observed continuously, individuals may have briefly come into contact with other individuals, or with the stream, without this being recorded, particularly at night, when frogs were active. While increasing the frequency of surveys would allow a more accurate estimate of opportunities for transmission, the relative differences between species are unlikely to change. Increasing survey frequency would also increase the probability of disturbing frogs and hence influencing their behaviour.

Despite its importance, contact between host and pathogen is only one part of the entire sequence of host-parasite interactions, beginning with pathogen survival in the environment and terminating in either host mortality or pathogen elimination. Even when a pathogen and its host come into contact with each other, successful invasion of the host by the pathogen is not guaranteed. For example, many fungal pathogens require very specific environmental conditions in order to be infective, and low humidity may completely prevent fungal pathogens from infecting potential hosts, regardless of how many spores are in contact with a potential host (Hajek \& St Leger 1994). Other factors such as host microenvironment selection may also eliminate infection once it occurs, since exposure to temperatures of $37^{\circ} \mathrm{C}$ for $<6 \mathrm{~h}$ can eliminate infection from captive Litoria chloris (Woodhams et al. 2003). Timing of transmission may therefore be extremely important. In particular, as host mortality due to chytridiomycosis is highest in winter, exposure to Batrachochytrium dendrobatidis during the winter months may have greater consequences for host survival.

In summary, due to behavioural differences, Litoria lesueuri, L. genimaculata and L. nannotis differ greatly in their rates of contact with other frogs, stream water and different environmental substrate types. Because these rates are likely to affect their levels of exposure to Batrachochytrium dendrobatidis, the transmission of $B$. dendrobatidis is likely to also differ between species. Frequency of frog-to-frog contact and contact with water are correlated with the conservation status of the frogs; the highest rates of contact between frogs and with water occurred in L. nannotis, the species most susceptible to chytridiomycosis-related declines, intermediate rates occurred in L. genimaculata, the species with intermediate susceptibility to decline, and the lowest rates occurred in $L$. lesueuri, the species least susceptible to chytridiomycosis-related declines. Interspecific variation in transmission may therefore play a role in determining why chytridiomycosis drives some populations to extinction and not others.

Acknowledgements. This research was supported by funding from the Australian Geographic Society, the Society for the Study of Amphibian and Reptiles, the Peter Rankin Trust Fund for Herpetology, the Australian Government Department of Environment and Heritage, and from US National Science Foundation Integrated Research Challenges in Environmental Biology Grant DEB-0213851, and was carried out under Scientific Purposes Permits issued by the Queensland Parks and Wildlife Service (WISP01715204 and WITK01715604) as approved by the James Cook University Animal Care and Ethics Committee (A863). J.J.L.R. was supported by an Australian Postgraduate Award. Thanks also to the many volunteers who assisted in the field and R. Speare, L. Schwarzkopf, R. Puschendorf and A. Phillott for many helpful comments on earlier drafts of the manuscript.

\section{LITERATURE CITED}

Altizer SM, Oberhauser KS, Brower LP (2000) Associations between host migration and the prevalence of a protozoan parasite in natural populations of adult monarch butterflies. Ecol Entomol 25:125-139

Anderson RM, May RM (1979) Population biology of infectious diseases, Part I. Nature 280:361-367

Anderson RM, May RM (1981) The population dynamics of microparasites and their invertebrate hosts. Proc R Soc Lond B 291:451-524

Arthurs S, Thomas MB (2001) Effect of dose, pre-mortem host incubation temperature and thermal behaviour on host mortality, mycosis and sporulation of Metarhizium anisopliae var. acridum in Schistocerca gregaria. Biocontrol Sci Technol 11:411-420

Begon M, Bennett M, Bowers RG, French NP, Hazel SM, Turner J (2002) A clarification of transmission terms in most-microparasite models: numbers, densities and areas. Epidemiol Infect 129:147-153

Bell BD, Carver S, Mitchell NJ, Pledger S (2004) The recent decline of a New Zealand endemic: How and why did populations of Archey's frog Leiopelma archeyi crash over 1996-2001? Biol Conserv 120:189-199

Berger L, Speare R, Daszak P, Green DE and 10 others (1998) Chytridiomycosis causes amphibian mortality associated with population declines in the rainforests of Australia and Central America. Proc Natl Acad Sci USA 95:9031-9036

Berger L, Speare R, Hines HB, Marantelli G and 10 others (2004) Effect of season and temperature on mortality in amphibians due to chytridiomycosis. Aust Vet J 82:434-439

Berger L, Marantelli G, Skerratt LF, Speare R (2005) Virulence of the amphibian chytrid fungus Batrachochytrium dendrobatidis varies with the strain. Dis Aquat Org 68: $47-50$

Bosch I, Martinez-Solano I, Garcia-Paris M (2001) Evidence of a chytrid fungus infection involved in the decline of the common midwife toad (Alytes obstetricans) in protected areas of central Spain. Biol Conserv 97:331-337

Bradley GA, Rosen PC, Sredl MJ, Jones TR, Longcore JE (2002) Chytridiomycosis in native Arizona frogs. J Wildl Dis 38:206-212 
Brown CR, Brown MB (1986) Ectoparasitism as a cost of coloniality in cliff swallows (Hirundo pyrrhonota). Ecology 67: 1206-1218

Brunner JL, Richards K, Collins JP (2005) Dose and host characteristics influence virulence of ranavirus infections. Oecologia 144:399-406

Cade BS, Richards JD (2005) User manual for Blossom statistical software. US Geological Survey, Reston, VA

Carey C, Bruzgul JE, Livo LJ, Walling ML and 5 others (2006) Experimental exposures of boreal toads (Bufo boreas) to a pathogenic chytrid fungus (Batrachochytrium dendrobatidis). EcoHealth 3:5-21

Coté I, Poulin R (1995) Parasitism and group size in social animals: a meta-analysis. Behav Ecol 6:159-165

Donnellan SC, Mahony MJ (2004) Allozyme, chromosmal and morphological variability in the Litoria lesueuri species group (Anura: Hylidae), including a description of a new species. Aust J Zool 52:1-28

Ezenwa V (2004) Host social behaviour and parasitic infection: a multifactorial approach. Behav Ecol 15:446-454

Fellers GM, Green DE, Longcore JE (2001) Oral chytridiomycosis in the mountain yellow-legged frog (Rana mucosa). Copeia 2001:943-953

Hajek AE, St Leger RJ (1994) Interactions between fungal pathogens and insect hosts. Annu Rev Entomol 39:293-322

Hero JM, Williams SE, Magnusson WE (2005) Ecological traits of declining amphibians in upland areas of eastern Australia. J Zool 267:221-232

Hoogland JL (1979) Aggression, ectoparasitism, and other possible costs of prairie dog (Sciuridae, Cynomys sp.) coloniality. Behavior 69:1-35

IUCN (Conservation International, NatureServe) (2006) Global amphibian assessment. Available at: www. globalamphibians.org. Accessed on 7 August 2006

Johnson ML, Speare R (2003) Survival of Batrachochytrium dendrobatidis in water: quarantine and disease control implications. Emerg Infect Dis 9:922-925

Johnson M, Berger L, Philips L, Speare R (2003) Fungicidal effects of chemical disinfectants, UV light, desiccation and heat on the amphibian chytrid, Batrachochytrium dendrobatidis. Dis Aquat Org 57:255-260

Langkilde T, Alford RA (2002) The tail wags the frog: harmonic radar transponders affect movement behavior in Litoria lesueuri. J Herpetol 36:711-715

Letcher PM, Powell MJ (2002) Frequency and distribution patterns of zoosporic fungi from moss-covered and exposed forest soils. Mycologia 94:761

Letcher PM, McGee PA, Powell MJ (2004) Distribution and diversity of zoosporic fungi from soils of four vegetation types in New South Wales, Australia. Can J Bot 82: $1490-1500$

Lips KR, Donnelly MA (2002) What the tropics can tell us about declining amphibian populations: current patterns and future prospects. In: Lannoo MJ (ed) North American amphibians: status and conservation. University of California Press, Berkeley, CA, p 388-406

Lips KR, Reeve JD, Witters LR (2003) Ecological traits predicting amphibian population declines in Central America. Conserv Biol 17:1078-1088

Lips KR, Burrowes PA, Mendelson JR, Parra-Olea G (2005) Amphibian declines in Latin America: widespread population declines, extinctions, and impacts. Biotropica 37: 163-165

Lips KR, Brem F, Brenes R, Reeve JD and 6 others (2006) Emerging infectious disease and the loss of biodiversity in a neotropical amphibian community. Proc Natl Acad Sci USA 103:3165-3170
Loehle C (1995) Social barriers to pathogen transmission in wild animal populations. Ecology 76:326-335

Longcore JE, Pessier AP, Nichols DK (1999) Batrachochytrium dendrobatidis gen. et sp. nov., a chytrid pathogenic to amphibians. Mycologia 91:219-227

McCallum H, Barlow N, Hone J (2001) How should pathogen transmission be modelled? Trends Ecol Evol 16:295-300

McDonald KR (2002) Frog futures: conservation issues and prospects for Queensland In: Nattrass AEO (ed) Frogs in the community. Proceedings of the Brisbane Symposium. Queensland Frog Society, East Brisbane, p 6-22

McDonald K, Alford RA (1999) A review of declining frogs in northern Queensland. In: Campbell A (ed) Declines and disappearances of Australian frogs. Environment Australia, Canberra, p 14-22

McDonald KR, Méndez D, Müller R, Freeman AB, Speare R (2005) Decline in the prevalence of chytridiomycosis in frog populations in North Queensland, Australia. Pac Conserv Biol 11:114-120

Muths E, Corn PS, Pessier AP, Green DE (2003) Evidence for disease-related amphibian decline in Colorado. Biol Conserv 110:357-365

Nichols DK, Lamirande EW, Pessier AP, Longcore JE (2001) Experimental transmission of cutaneous chytridiomycosis in dendrobatid frogs. J Wildl Dis 37:1-11

Parris KM, Cornelius TO (2004) Fungal pathogen causes competitive and developmental stress in larval amphibian communities. Ecology 85:3385-3395

Pessier AP, Nichols DK, Longcore JE, Fuller MS (1999) Cutaneous chytridiomycosis in poison dart frogs (Dendrobates spp.) and White's tree frogs (Litoria caerulea). J Vet Diagn Invest 11:194-199

Rachowicz LJ, Vredenburg VT (2004) Transmission of Batrachochytrium dendrobatidis within and between amphibian life stages. Dis Aquat Org 61:75-82

Rachowicz LJ, Knapp RA, Morgan JAT, Stice MJ, Vredenburg VT, Parker JM, Briggs CJ (2006) Emerging infectious disease as a proximate cause of amphibian mass mortality. Ecology 87:1671-1683

Retallick RW (2002) Using experimental translocations to learn about declines in Queensland's frog populations. Implementation of Queensland's threatened frog recovery plans-experimental ecology. Queensland Parks and Wildlife Service, Atherton

Retallick RWR, McCallum H, Speare R (2004) Endemic infection of the amphibian chytrid fungus in a frog community post-decline. PLoS Biol 2:e351

Richards SJ, Sinsch U, Alford RA (1994) Radio tracking. In: Heyer WR, Donnelly MA, McDiarmid RW, Hayek LC, Foster MS (eds) Measuring and monitoring biological diversity: standard methods for amphibians. Smithsonian Institution Press, Washington, DC, p 155-157

Rowley JJL, Alford RA (2007) Techniques for tracking amphibians: the effects of tag attachment, and harmonic direction finding versus radio telemetry. Amphib-Reptilia (in press)

Rowley JJL, Skerratt LF, Alford RA, Campbell R (2007) Retreat sites of rain forest stream frogs are not a reservoir for Batrachochytrium dendrobatidis in northern Queensland, Australia. Dis Aquat Org 74:7-12

Stuart SN, Chanson JS, Cox NA, Young BE, Rodrigues ASL, Fischman DL, Waller RW (2004) Status and trends of amphibian declines and extinctions worldwide. Science 306:1783-1786

Swinton J (1998) Extinction times and phase transitions for spatially structured closed epidemics. Bull Math Biol 60: $215-230$ 
van Beek N, Hughes PR, Wood HA (2000) Effects of incubation temperature on the dose-survival time relationship of Trichoplusia ni larvae infected with Autographa Californica Nucleopolyhedrovirus. J Invertebr Pathol 76:185-190

Vermeer K (1969) Endoparasitic variation between California gulls and ring-billed gulls. Ibis 111:393-395

Watanabe H (1987) The host population. In: Fuxa JR, Tanada $\mathrm{Y}$ (eds) Epizootiology of insect diseases. John Wiley \& Sons, New York, p 71-112

Weldon C, Du Preez L (2004) Decline of the Kihansi spray toad, Nectophrynoides asperginis, from the Udzungwa Mountains, Tanzania. Froglog 62:2-3

Editorial responsibility: Alex Hyatt,

Geelong, Victoria, Australia
Williams SE, Hero JM (1998) Rainforest frogs of the Australian wet tropics: guild classification and the ecological similarity of declining species. Proc R Soc Lond B 265:597-602

Wobeser G, Hunter DB, Wright B, Nieman DJ, Isbister R (1979) Avian cholera in waterfowl in Saskatchewan in spring. J Wildl Dis 15:19-24

Woodhams DC, Alford RA (2005) The ecology of chytridiomycosis in rainforest stream frog assemblages of tropical Queensland. Conserv Biol 19:1449-1459

Woodhams DC, Alford RA, Marantelli G (2003) Emerging disease of amphibians cured by elevated body temperature. Dis Aquat Org 55:65-67

Submitted: February 27, 2007; Accepted: May 28, 2007 Proofs received from author(s): July 18, 2007 